\title{
VIBRATION LEVEL EVALUATION OF ENGINES FUELED WITH BRAZILIAN COMMERCIAL DIESEL AND BIODIESEL
}

\author{
José Lima Júnior \\ Federal Center for Technological Education of Minas Gerais (CEFET-MG), Dept. of Mechatronics, ZIP Code 37022-560, \\ Varginha-MG, Brazil \\ Corresponding author: limajr36@gmail.com
}

\section{Ricardo Rodrigues Magalhaes}

Federal University of Lavras (UFLA), Dept. of Automation, ZIP Code 37200-000, Lavras-MG, Brazil

\author{
Danton Diego Ferreira \\ Federal University of Lavras (UFLA), Dept. of Automation, ZIP Code 37200-000, Lavras-MG, Brazil
}

\author{
Paulo Henrique Cruz Pereira \\ Federal Center for Technological Education of Minas Gerais (CEFET-MG), (DMCVG) Dept. of mechatronics, ZIP Code \\ 37022-560, Varginha-MG, Brazil
}

\begin{abstract}
This paper is aimed to analyze vibrations from engines fueled with two different fuels, Brazilian commercial diesel (B8) and Biodiesel (B100). Consumption, level of particulate matter emissions and engine temperature were also analyzed. The experiments were performed considering noninvasive tests in a diesel engine, taking into account three different speeds: $800 \mathrm{rpm}, 1800 \mathrm{rpm}$ and $3600 \mathrm{rpm}$. Results showed that the engine energetic loss from vibration signals collected allowed a quantitative assessment of how each fuel influenced the engine vibration level. In the three analyzed speeds, B8 diesel fuel showed be more energetic when compared to B100 biodiesel fuel. Although the consumption using B100 biodiesel fuel presented higher values than B8, the level of particulate matter emissions was lower than commercial diesel B8. It was also noted that the vibration increased in both cases when the engine speed increased. B8 diesel presented a total vibration varying according to speeds range, from $4.5 \%$ to $21 \%$ higher than B100 biodiesel. Therefore, the dissipated vibration energy using B8 diesel was higher (10\% to $45 \%)$ than B100 biodiesel. It is concluded that combustion is one of the item that generates higher level of vibration in diesel engines and it depends on the kind of fuel used.
\end{abstract}

Index terms: Internal combustion engines, Biocombustible, Oscillation.

Received: July, 31, 2019 - Accepted: March, 05, 2020

\section{INTRODUCTION}

Biodiesel is an alternative diesel fuel which is derived from vegetable oils or animal fats. It has been the focus of a considerable amount of recent research because it is renewable and reduces the emission of some pollutants (Monyem and Van Gerpen, 2001). According to Brazilian National Petroleum Agency (ANP, 2019), Brazil must achieve the goal established by the Treaty of Paris COP 21 (2019) which represents a reduction of $37 \%$ in greenhouse gas emissions by 2025 and $43 \%$ by 2030 . Based on that, it will be necessary to increase the percentage of biodiesel added to fossil diesel, which could reach $15 \%$ by 2023 (Figure 1). The increase in the use of biodiesel fuels should therefore overcome this value in order to achieve the goals established in the Treaty of Paris (COP 21, 2019).

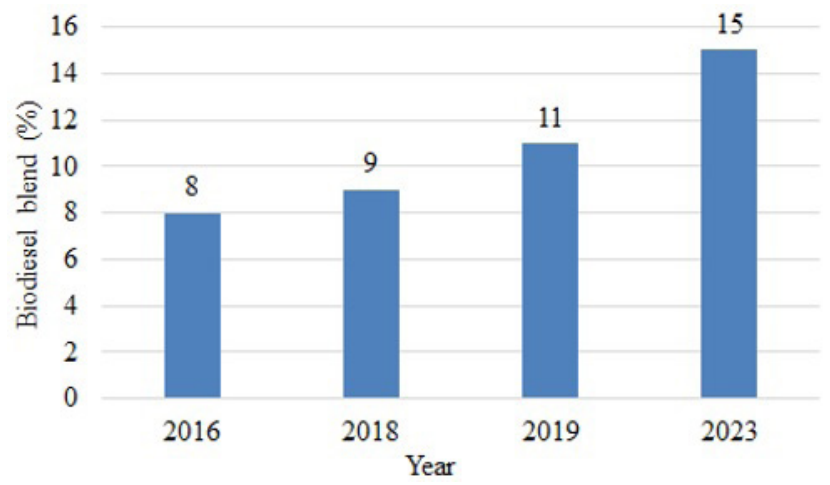

Figure 1: Percentage of biodiesel in fossil diesel. 
In this context, researchers have developed works related to the use of alternative fuels, in which the advantages and disadvantages of them, in terms of both consumption and gas emission, have been presented and discussed. Volpato et al. (2009) performed measurements on a multi-cylindrical engine, fueled with B100 biodiesel fuel. It was verified that the engine obtained a torque gain and had a lower specific consumption when compared to the use of fossil diesel. This study also showed that a diesel cycle engine may perfectly work with B100 biodiesel fuel without problems in terms of torque and consumption. Perin et al. (2017) performed test on eleven different kinds of biodiesel fuels. Results indicate that the increase of biodiesel in mineral diesel reduces torque and power, increases the specific fuel consumption and does not change consumption. Yusop et al. (2018) stated that B100 biodiesel fuel showed lower engine power at higher brake-specific fuel consumption when compared to other biodiesel fuels. Wei, Cheung and Ning (2018) compare effects of biodiesel-ethanol and biodiesel-butanol blends on combustion, performance and emissions of a direct-injection diesel engine.

Uludamar et al. (2016) investigated the vibration effect of canola, sunflower biodiesel and their blends with low Sulphur diesel fuel in a four cylinder four stroke diesel engine at different engine speeds. Heywood (1988) stated that vibration results from combustion vary according to the kind of fuel used. Usually, vibration index is higher in diesel engines as result of the compression ratio which varies from 17:1 to 23:1, while Otto cycle engines varies from 9:1 to 14:1. Engine vibrations are normally generated by the combustion process from cylinder walls and valves. The engine is therefore the main source of vehicles vibration and it can be felt by the occupants of the vehicle. Engine vibrations are also originated from mechanical loads and it may compromise the structural integrity of the components.

Combustion process normally causes horizontal vibrations from the engine block, the axial vibrations from the engine crankshaft and vertical vibrations from the combustion chamber. Heidary et al. (2013) performed vibration analysis of a small diesel engine using diesel-biodiesel fuel blends and noted that the magnitude of vibrations in vertical axis was higher than axial vibrations. However, vertical vibration analysis is more appropriate as result of the combustion process.

Vibration originated from the combustion process is caused by the explosion reaction of the air fuel mixture under high pressure and temperature inside the combustion chamber. The kind of fuel used has influence on it, which establishes particular characteristics for this kind of analysis. Due to its high compression ratio, diesel engine vibrations have higher level than Otto cycle engines. Chum and Kim (1994) analyzed an engine block vibration from a fourcylinder engine. For this, a derivative third filter method was used and authors confirmed that vibration signals study can be used to avoid resonant frequencies which may be harmful for the machine.

Studies for fault diagnostics in combustion engines through the analysis of vibrations were performed by $\mathrm{Wu}$ and Chuang (2005). In this study, vibration and acoustic signals were analyzed. These signals were used to monitor different speed ranges of a machine through a digital comparison of images in which such comparisons resulted in failure or not failure.

Changing parameters of the fuel injection system can also affect the vibrations at different points in the engine block. This was observed by Carlucci, Chiara and Laforgia (2006), which used accelerometers at different points of the engine block varied parameters such as time, quantity and fuel injection pressure and performed time-frequency analyzes. Vibration states of engine fueled with diesel fuel and biodiesel are different and the advanced ignition of biodiesel is the main cause of the nonlinear increase in root mean square (RMS) of vibration response (Yang et al. 2018).

It is known that lower is the engine vibration as result of biodiesel fuel decreasing compared to fossil diesel, but researches involving intermediate percentages of biodiesel added to fossil diesel, such as $8 \%$ in Brazil, is still incipient. Based on that, this paper is focused on analyzing vibrations from engine fueled with two different fuels, commercial Brazilian diesel (B8) and Biodiesel (B100). For this, three different 
speeds (800 rpm, $1800 \mathrm{rpm}$ and $3600 \mathrm{rpm}$ ) were used. Besides this introduction section, section 2 presents materials and methods used, results and discussion are presented in section 3 and the conclusions are presented in section 4 .

\section{MATERIAL AND METHODS}

The engine used for the experiments was an IVECO assembled on elastic supports, four stroke diesel engine, 2.3-liter, 16 valves, standard 127 horsepower at $3600 \mathrm{rpm}, 67.68 \mathrm{lb}$.-ft. maximum torque at $1800 \mathrm{rpm}, 19: 1$ compression rate, direct injection turbocharged and electronic control.

Two different fuels were used in the experiments: commercial Brazilian diesel (B8) which corresponded to $8 \%$ of biodiesel added to fossil diesel and Biodiesel (B100) which corresponded to $100 \%$ of castor oil biodiesel. According to ASTM D7467 and ASTM D6751 (2019), B8 and B100 must follow physicochemical specifications, respectively, which are presented in Table 1.

Table 1: B8 and B100 main physicochemical properties (ASTM, 2019).

\begin{tabular}{ccc}
\hline Specification & B8 & B100 \\
\hline Flash Point, ${ }^{\circ} \mathrm{C}$, min & 52 & 130 \\
Viscosity, $\mathrm{mm} 2 / \mathrm{s}$ at $40^{\circ} \mathrm{C}$ & $1.9-4.1$ & $1.9-6.0$ \\
Cetane Number, min & 40 & 47 \\
$\quad$ Acid Number, max & 0.3 & 0.5 \\
$\begin{array}{c}\text { Distillation Temperature, }{ }^{\circ} \mathrm{C}, \\
\text { 90\% vol recovered, max }\end{array}$ & 343 & 360 \\
\hline Oxidation Stability, hours, min & 6 & 3 \\
\hline
\end{tabular}

The engine chosen for the tests worked with speeds ranges from $800 \mathrm{rpm}$ to $6000 \mathrm{rpm}$ and followed the recommendations from NBR ISO 20816-1 (ABNT, 2016), which recommends a range from $10 \mathrm{~Hz}$ to $1000 \mathrm{~Hz}$. Three different engine speeds were analyzed: $800 \mathrm{rpm}$ which corresponds to idle, $1800 \mathrm{rpm}$ which corresponds to the speed for the maximum engine torque and $3600 \mathrm{rpm}$ which is the speed where the engine develops its maximum power. According to Arnone et al. (2009), speeds definition for vibration analysis in diesel engine blocks should follow individual criteria for each engine type, taking in to account the combustion phases and the individual characteristics of each engine.
In order to control the pre-defined speeds, a device assembled close to the vehicle accelerator pedal was developed in order to achieve a specific engines speed (Figure 2). By using this device, it was possible to adjust different pedal accelerator positions, being possible to control the engine speed. The right position of the accelerator pedal was helped by a vehicle scanner, which provided more accurate engine speed, allowing precision and repeatability.

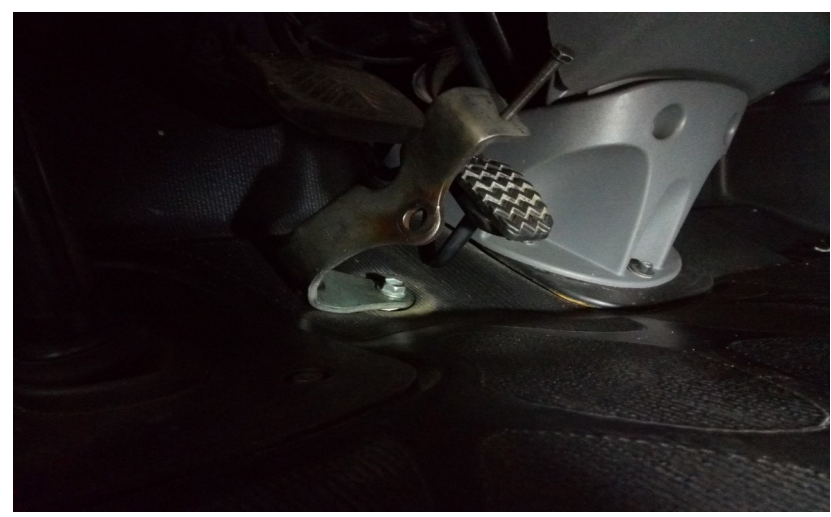

Figure 2: Screw for speed controlling.

Experiments were performed considering three times at each speed $(800 \mathrm{rpm}, 1800 \mathrm{rpm}$ and $3600 \mathrm{rpm}$ ). For each fuel (B8 diesel and B100 biodiesel), an interval of 5 minutes between each experiment was adopted for components position and engine temperature stabilization. Tests were carried out on two consecutive days during similar periods of the day, which ensured that the ambient temperature variation was the lowest as possible. The ambient temperature at the beginning of the first day test was $31.5^{\circ} \mathrm{C}$ and at the end of the tests was $32.5^{\circ} \mathrm{C}$. At the second day, measured ambient temperature was $30^{\circ} \mathrm{C}$ at the day beginning and $32.5^{\circ} \mathrm{C}$ at the end of the day of experiments.

The first phase of the experiments was performed by using B8 diesel fuel and in the second phase, B100 biodiesel fuel was used. The exchange of fuels took place with the aid of an electric pump, ensuring that B8 diesel fuel was totally removed from the system before the exchange for B100 biodiesel fuel.

The experiments performed for both fuels were based on NBR 10082 standard ABNT (2011), which deals with non-destructive tests and vibration analyzes on machines working 
in fixed or variable speeds in a range up to $15000 \mathrm{rpm}$. This parameter was used due to the fact that vibrations in frequency signals can vary from $10 \mathrm{~Hz}$ to $1500 \mathrm{~Hz}$. In order to determine the vibration intensity, the highest measured amplitude was used. Acceleration was used to analyze high frequencies, which stated that values used for measure vibration index are directly related to the definition of its magnitude.

Accelerometers were installed at the top of the engine, where we have the highest levels of vibration due to combustion, for acquisition of vertical (perpendicular to the engine main axis and aligned to the working cylinders) and horizontal (perpendicular to the main axis and working cylinders) Figure 3. The horizontally installed accelerometers obtained vibration signals from the moving parts of the engine and the vertical-mounted accelerometers obtained vibration signals from successive combustions, as suggested by Arnone et al. (2009); Carlucci, Chiara and Laforgia (2006). Vibration signals were provided by a computer audio input. In addition, a vibration analyzer was used to validate vibration signal measurements.

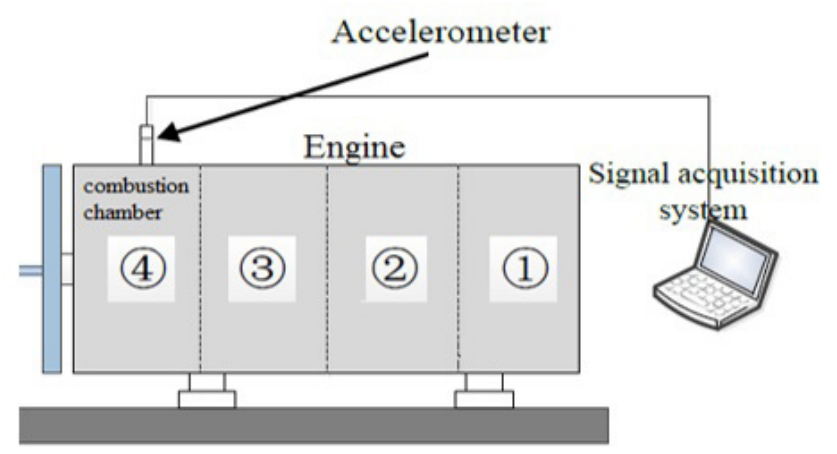

Figure 3: Accelerometer installation position.

\section{Calculation}

The overall vibration index can be defined as the total vibration energy dissipated and measured within a given specific frequency range in all directions (Rao, 2009). In accordance with NBR ISO 20816-1 ABNT (2016), vibration limits are specified taking in to account values measured in RMS values from the related vibration measurements, Equation 1. $a_{w}=\sqrt{\frac{1}{t} \int_{0}^{t} a^{2}(t) d t}$

where $a_{w}$ is the weighted acceleration and $t$ represents the measurement time.

The total acceleration is a vector expression considering the resultant of vibration in the vertical, horizontal and axial directions, Equation 2.

$a_{w}=\sqrt{\frac{1}{t} \int_{0}^{t} a^{2}(t) d t}$

where $A, H$ and $V$ are, respectively, the vibration in the axial, horizontal and vertical positions and $a_{t}$ is the total vibration acceleration.

The index of energy vibration (IEV) was calculated by the product of the engine mass, the frequency of excitation and the squared vibration speed, according to Equation 3.

$I E V=\frac{\left(m v^{2} f\right)}{2}$

where $I E V$ is the energy index of vibration, $m$ is the engine mass, $f$ is the frequency from engine excitation and $v$ is the vibration speed.

\section{RESULTS AND DISCUSSION}

Engine vibration signals considering vertical (from combustion) positions at $800 \mathrm{rpm}$ (idling motor), $1800 \mathrm{rpm}$ (higher torque) and 3600 rpm (maximum power) when fueled with B8 diesel and B100 biodiesel fuels are presented respectively (Figures 4, 5, 6, 7, 8, 9).

According to the graphs above, the engine vibration speeds at $800 \mathrm{rpm}$ in the vertical position (from combustion) did not show significant differences considering the fuel change, but the valueswere close to the total vibration speed. The vertical speed for B8 diesel was $14.24 \mathrm{~mm} / \mathrm{s}$ and $3.65 \mathrm{~mm} / \mathrm{s}$ for B100 biodiesel (about $4 \%$ higher). Considering the engine vibration speed at $1800 \mathrm{rpm}$ in an upright position with both fuels resulted in a variation of around $11 \%$. Engine vibration speed with B8 diesel was 21.2 $\mathrm{mm} / \mathrm{s}$ and engine vibration speed with B100 biodiesel was $18.96 \mathrm{~mm} / \mathrm{s}$. Remembering that in 
the vertical position is where we can capture the speed of vibration from combustion.

Considering the engine vibration speed at 3600 rpm, B8 diesel and B100 biodiesel fuels had similar behaviors. B100 biodiesel presented values around $28.55 \mathrm{~mm} / \mathrm{s}$ and B8 diesel presented 33.81 $\mathrm{mm} / \mathrm{s}$, which represents a difference around $18 \%$
(Figures 6 and 7). Figure 10 shows the variation of the vibration velocity values in the vertical position (from combustion) at the three revs analyzed, while Figure 11 shows the variation of the total motor vibration velocity, which is the total resultant of the vibration velocity from all exciter bodies in the system.

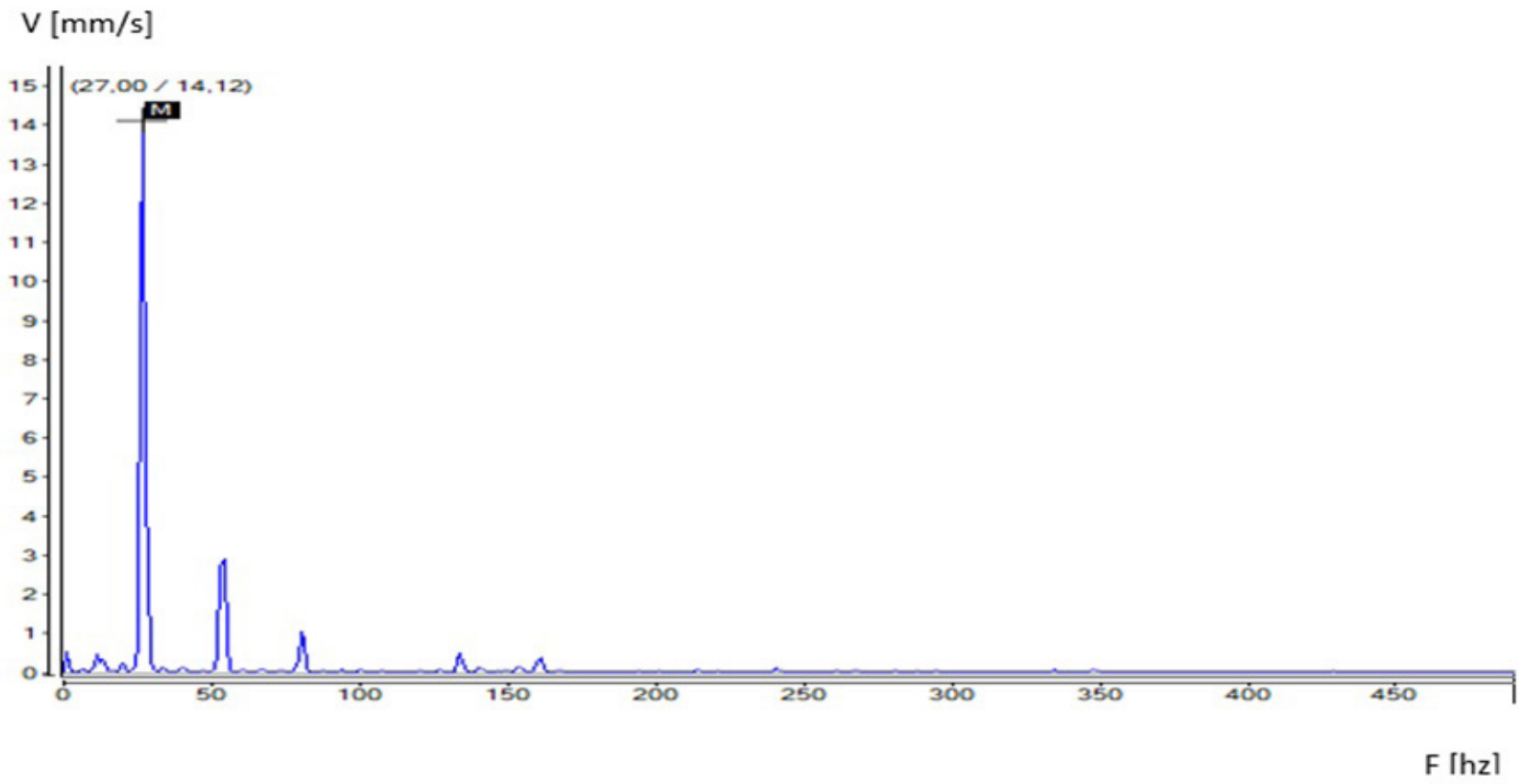

Figure 4: B8 (800 rpm).

\section{$\mathrm{V}[\mathrm{mm} / \mathrm{s}]$}

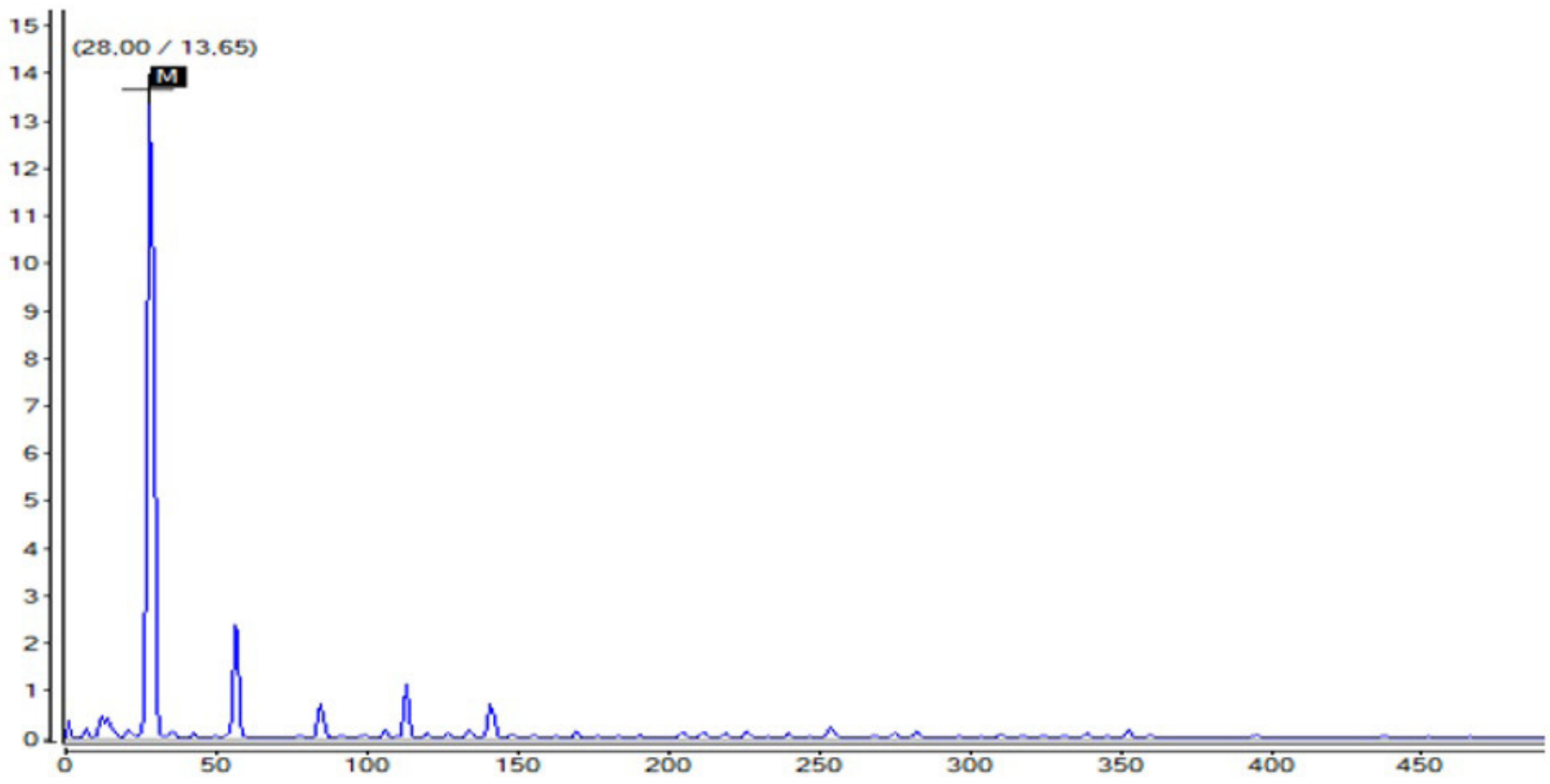

Figure 5: B100 (800 rpm). 


\section{$\mathrm{V}[\mathrm{mm} / \mathrm{s}]$}

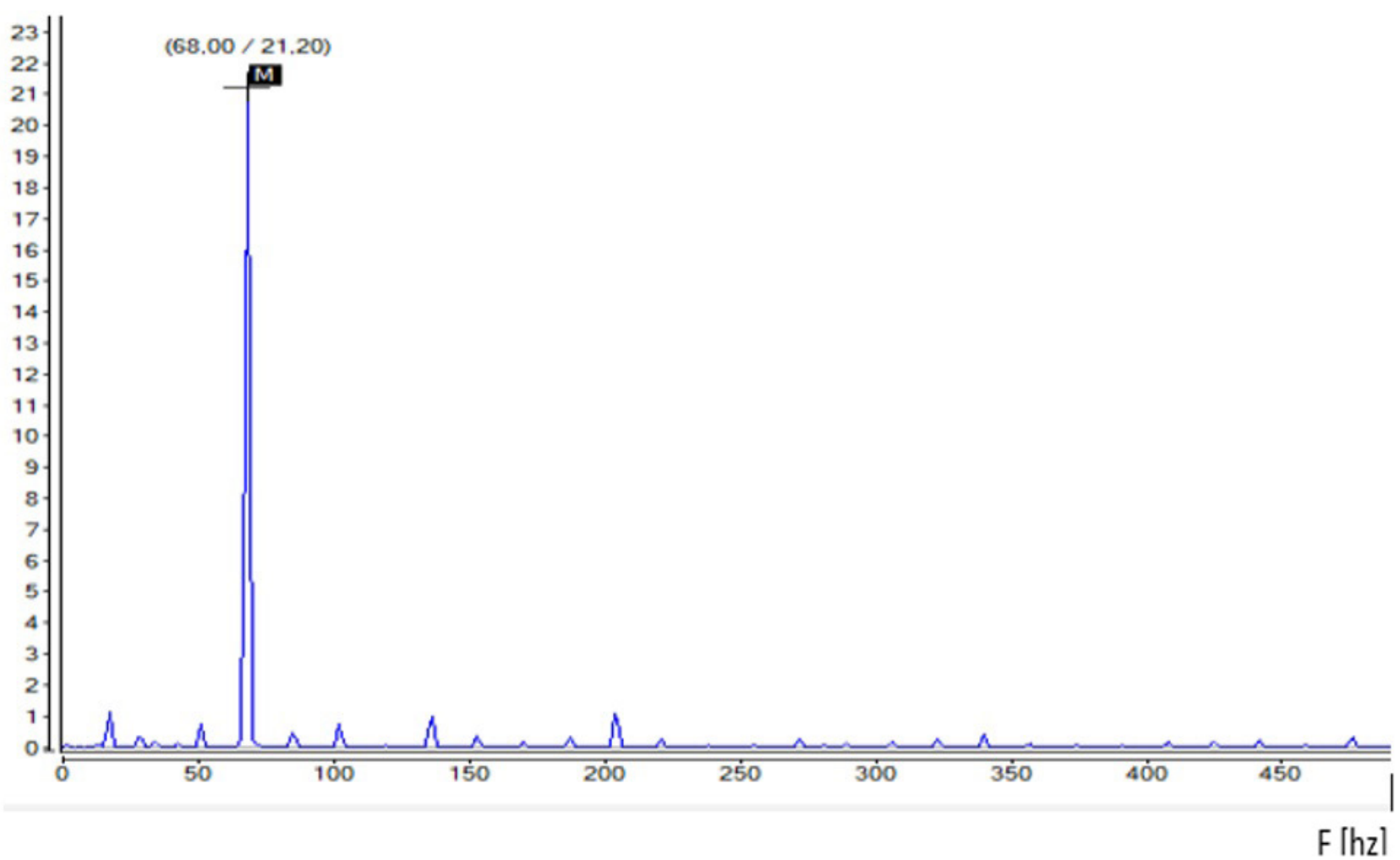

Figure 6: B8 (1800 rpm).

\section{$\mathrm{V}[\mathrm{mm} / \mathrm{s}]$}

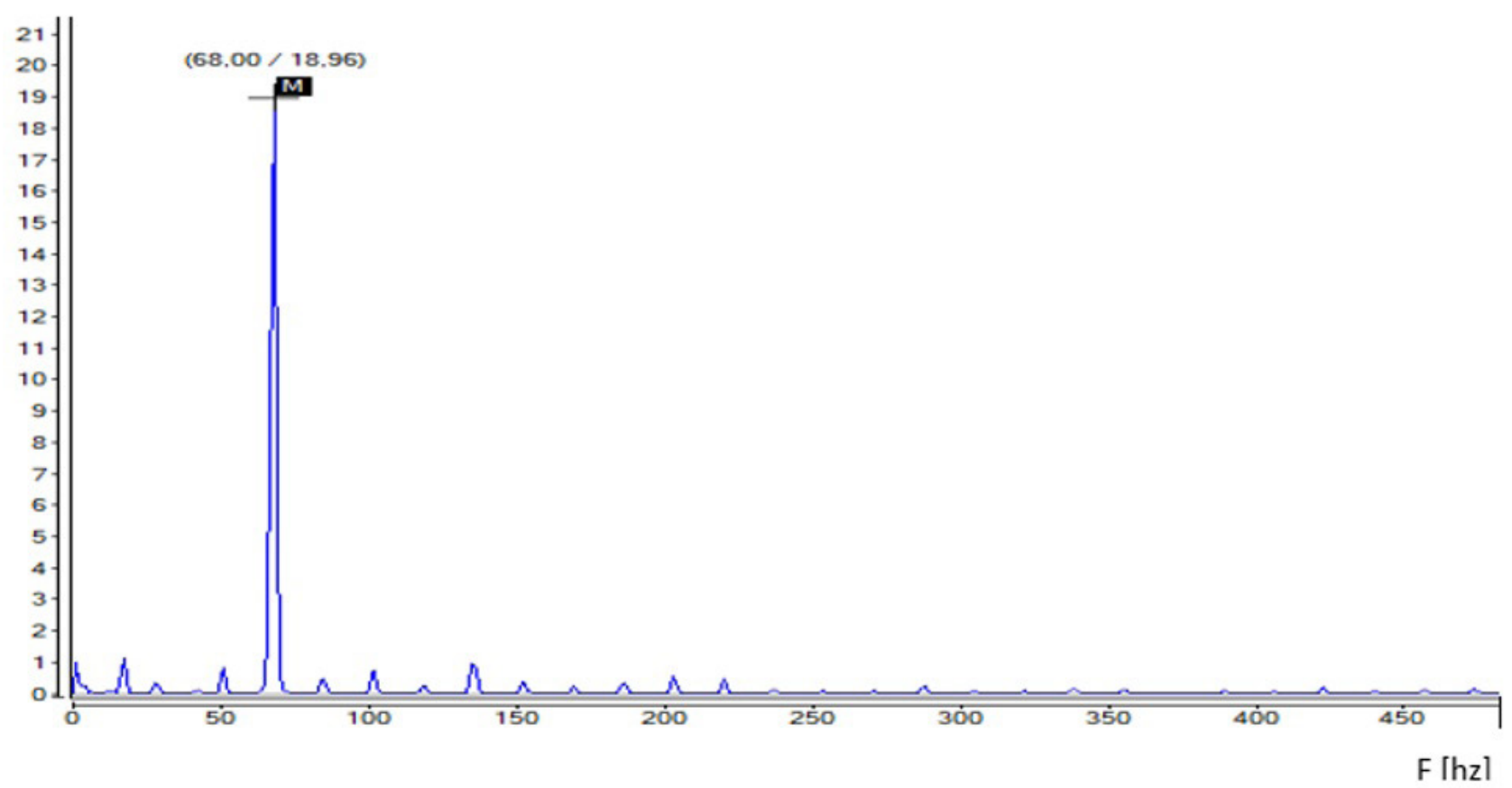

Figure 7: B100 (1800 rpm). 
$\mathrm{V}[\mathrm{mm} / \mathrm{s}]$

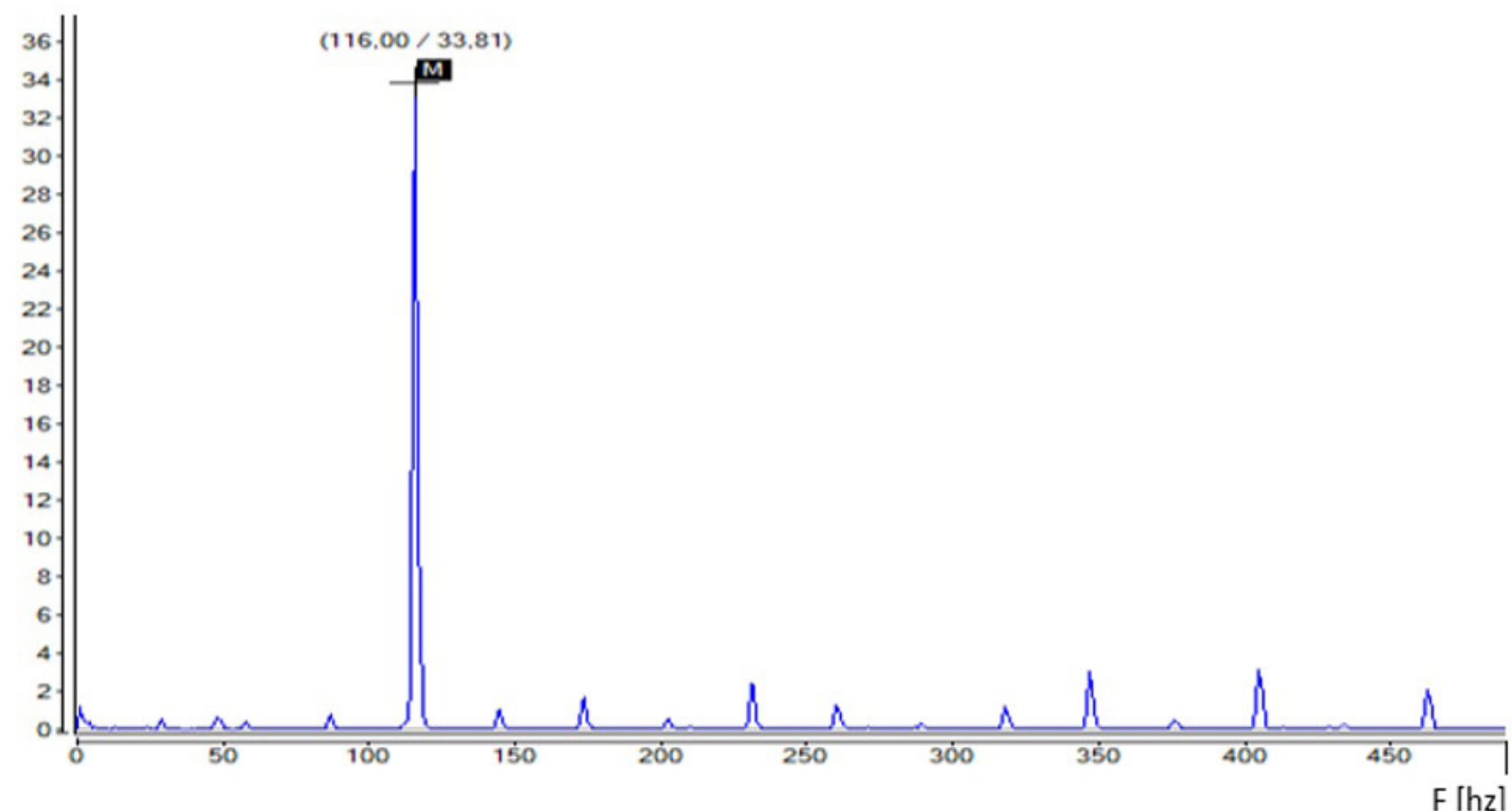

Figure 8: B8 (3600 rpm).

\section{$\mathrm{V}[\mathrm{mm} / \mathrm{s}]$}

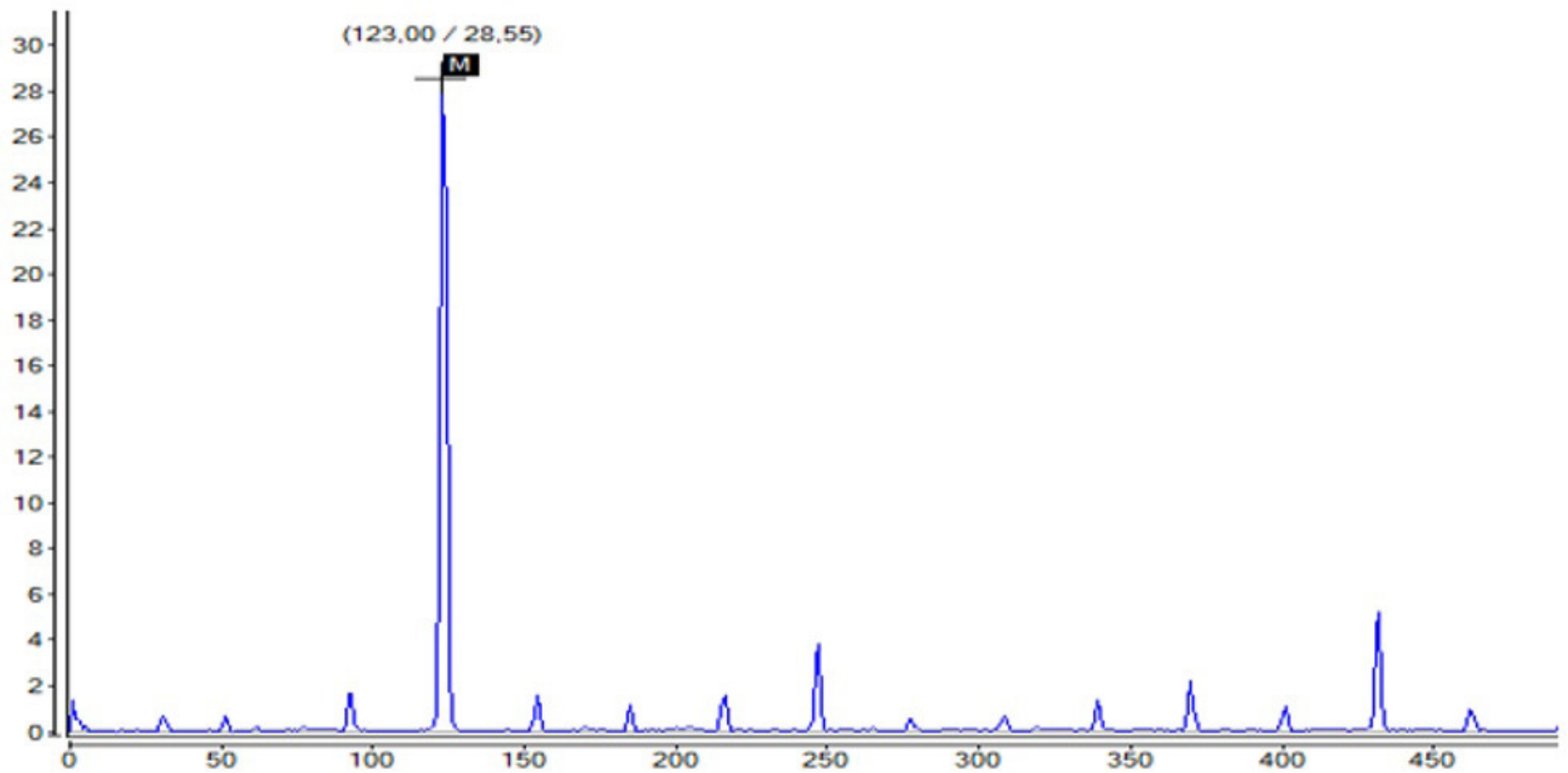

Figure 9: B100 (3600 rpm). 


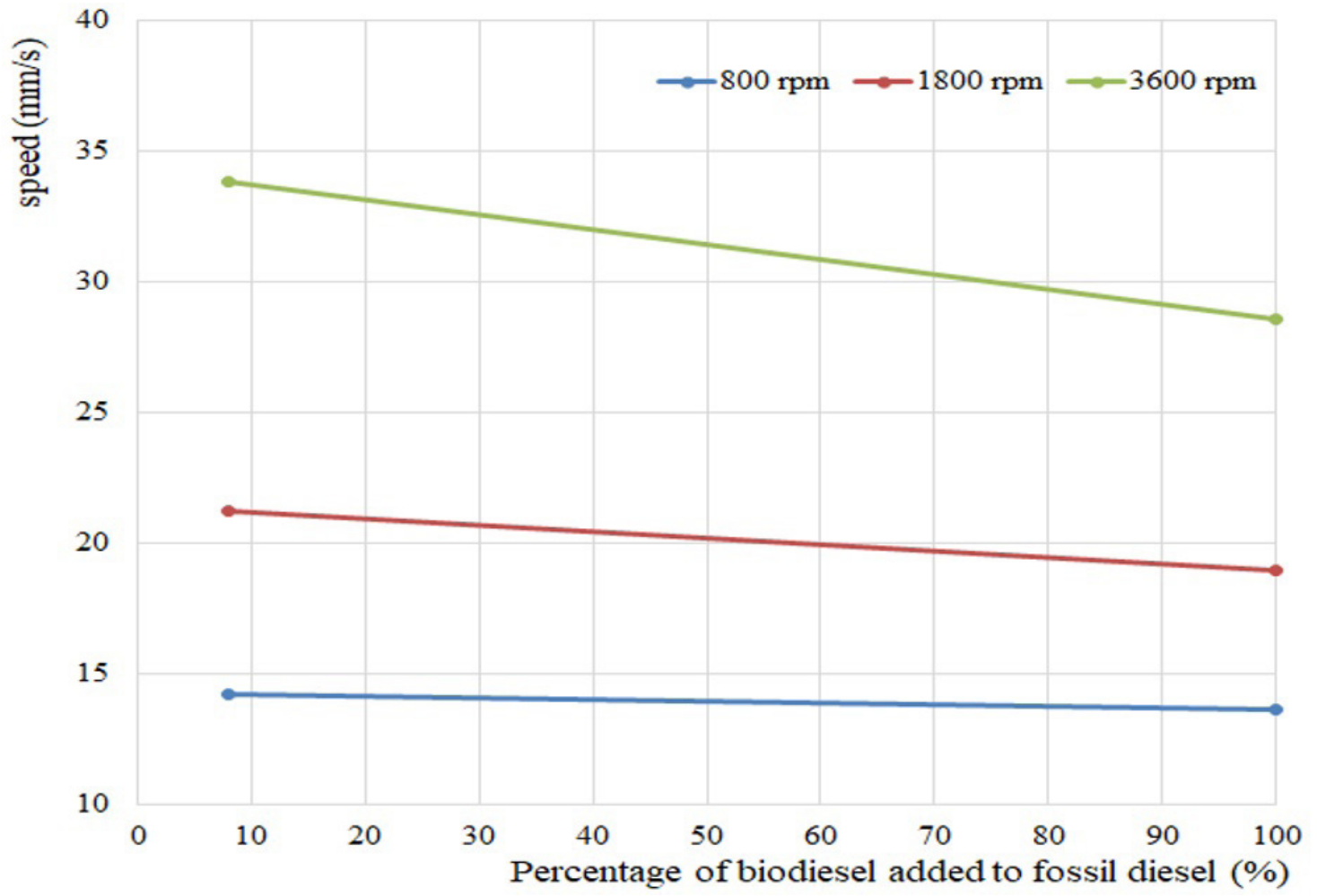

Figure 10: Vertical vibration speed.

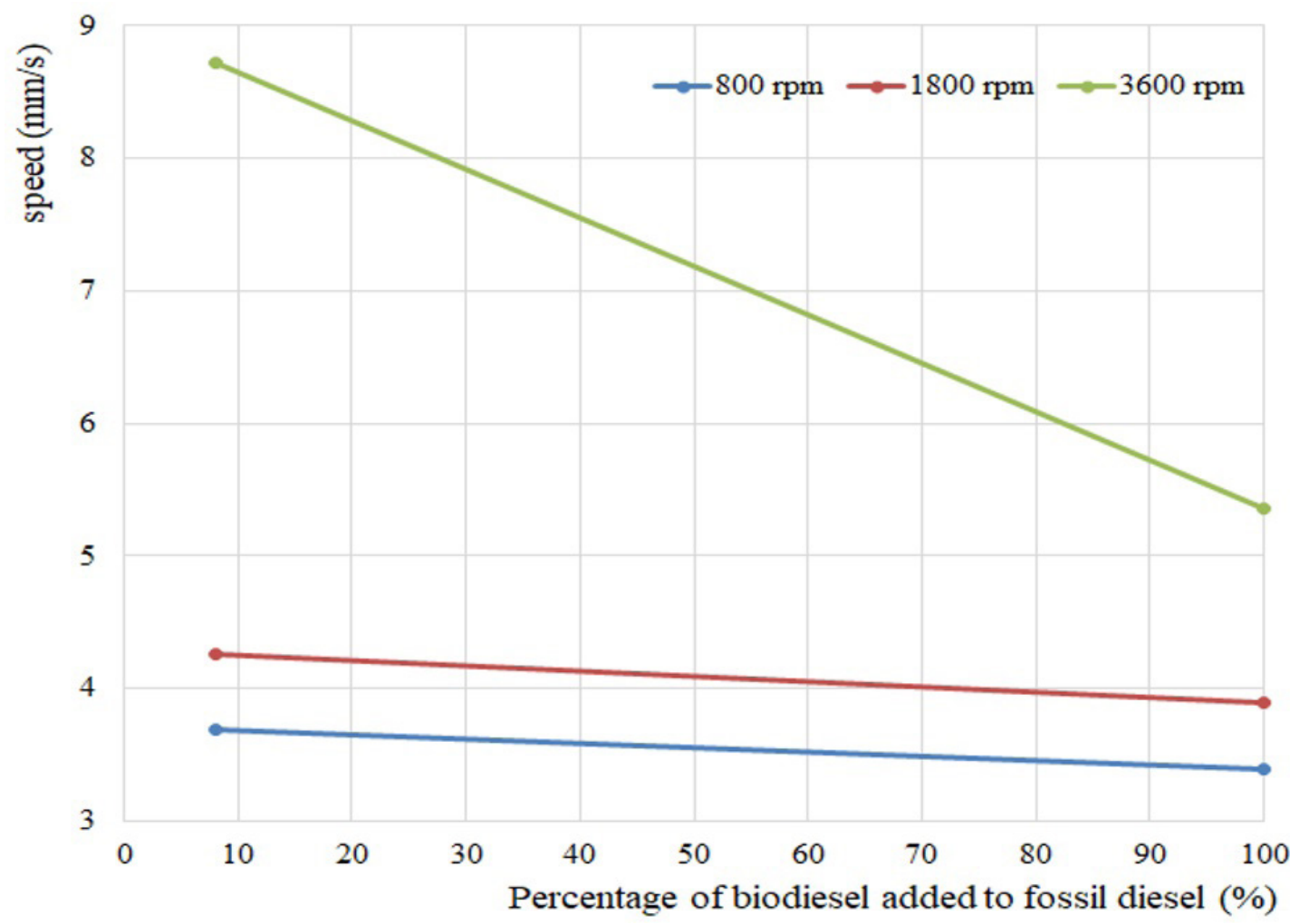

Figure 11: Total vibration speed.

The energy vibration index (IEV) was calculated to observe the total amount of energy available in the engine, fuel, fuel and vibration effect consumption during the same operation.
By analyzing the IEV, at the pre-defined speeds (800 rpm, $1800 \mathrm{rpm}$ and $3600 \mathrm{rpm}$ ), it is noted in Table 2 that B100 biodiesel fuel dissipated less energy in terms of vibration in the three analyzed speeds. 
Table 2: Index of energy vibration.

\begin{tabular}{ccc}
\hline & B100 & B8 \\
\hline IEV at $800 \mathrm{rpm}$ & $0.53 \mathrm{~W}$ & $0.56 \mathrm{~W}$ \\
IEV at $1800 \mathrm{rpm}$ & $2.42 \mathrm{~W}$ & $3.15 \mathrm{~W}$ \\
IEV at $3600 \mathrm{rpm}$ & $9.43 \mathrm{~W}$ & $13.72 \mathrm{~W}$ \\
\hline
\end{tabular}

Taking into account that the engine analyzed was designed to work with B8 diesel, which has lower density and viscosity according to Carlucci, Chiara and Laforgia (2006), it is noted in Table 2 that B100 biodiesel fuel worked with lower energy of vibration dissipation in both cases, around 25\% lower than B8 diesel fuel, varying according to the analyzed speed.

It is also noted that at lower speeds, for instance $800 \mathrm{rpm}, \mathrm{B} 8$ diesel fuel reached a total vibration average of $15.04 \mathrm{~mm} / \mathrm{s}$ and the B100 biodiesel fuel reached $14.44 \mathrm{~mm} / \mathrm{s}$, representing a difference of $4.5 \%$. In the speed of $1800 \mathrm{rpm}$, the variation was around $13 \%$. The B100 biodiesel fuel had a lower energy level of vibration, reaching an average speed of 19.96 $\mathrm{mm} / \mathrm{s}$, while the B8 diesel fuel reached 22.53 $\mathrm{mm} / \mathrm{s}$.

At $3600 \mathrm{rpm}, \mathrm{B} 8$ diesel fuel was more energetic, with a mean vibration index of $35.71 \mathrm{~mm} / \mathrm{s}$ against $29.57 \mathrm{~mm} / \mathrm{s}$ from B100 biodiesel fuel, which means that B8 results were $21 \%$ higher than B100 in terms of vibration index. However, the energy difference from 1800 to $3600 \mathrm{rpm}$ was around $45 \%$.

Vibrations variation from the piston movement and the combustion pressure was evidenced by means of the sensors position. Sensors installed in the vertical position were responsible for recording the acceleration signals. Total vibration acceleration in the three analyzed speeds for both fuels and the respective frequencies are presented in Table 3.

When speed values for both fuels were compared, based on standard NBR ISO 20816-1 ABNT (2016), it is verified that the values are within the unsatisfactory and unacceptable ranges. A verification analysis was performed on the vehicle and it was found that one of the support brackets was damaged, which was the probable cause of the increase of these values.

At the three revs analyzed (800, 1800 and $3600 \mathrm{rpm}$ ), the engine running on B8 diesel had a higher vibration speed index than B100 biodiesel. Verify that the biggest difference occurred at the speed of $3600 \mathrm{rpm}$. With B8 diesel, use a vibration rate $17.5 \%$ higher than B100 fuel vibrations.

According to Carlucci, Chiara and Laforgia (2006), B100 fuel has viscosity higher than B8. Higher B100 biodiesel fuel viscosity may also cause delay in the combustion point. When the fuel was injected into the combustion chamber with a slight delay, the optimum point for the best use of the combustion has already happened. This phenomenon may cause a decrease in engine power resulting in a lower vibration index due to the atomization of the fuel being harder.

Considering the energy dissipation in terms of vibration, it was noted a low variation between the B8 diesel and B100 biodiesel fuels. This variation may have occurred as result of the mechanical part of the fuel injection system, which was not suitable for the high B100 biodiesel viscosity.

In addition, B100 biodiesel fuel presented lower vibration index, and, consequently, a lower energy loss. Results obtained from the experiments, considering the two fuels tested (B8 and B100) are presented in Table 4.

Table 3: Total speed and frequencies.

\begin{tabular}{ccccccc}
\hline Fuel & \multicolumn{3}{c}{ B8 } & \multicolumn{3}{c}{ B100 } \\
\hline Speed $(\mathrm{rpm})$ & 800 & 1800 & 3600 & 800 & 1800 & 3600 \\
\hline Speed $(\mathrm{mm} / \mathrm{s})$ & 15.04 & 22.53 & 35.71 & 14.44 & 19.96 & 29.57 \\
Frequency $(\mathrm{Hz})$ & 27.00 & 67.22 & 116.33 & 27.66 & 65.67 & 116.66 \\
Variation at 800 rpm & & & & $4.5 \%$ & & \\
Variation at 1800 rpm (\%) & & & \multicolumn{2}{c}{$13 \%$} & & \\
Variation at 3600 rpm (\%) & & & & $21 \%$ & & \\
\hline
\end{tabular}


Table 4: B8 and B100 fuels results comparison.

\begin{tabular}{|c|c|c|c|c|c|c|}
\hline \multirow{2}{*}{$\begin{array}{c}\text { Fuel } \\
\text { Speed (rpm) }\end{array}$} & \multicolumn{3}{|c|}{ B8 diesel } & \multicolumn{3}{|c|}{ B100 biodiesel } \\
\hline & 800 & 1800 & 3600 & 800 & 1800 & 3600 \\
\hline Consumption average $\left(\mathrm{mm}^{3} /\right.$ cycle $)$ & 9.32 & 6.31 & 8.36 & 10.46 & 7.47 & 9.82 \\
\hline Atmospheric pressure (mbar) & 901 & 901 & 901 & 903 & 904 & 903 \\
\hline Turbine pressure (mbar) & 901 & 914 & 1041 & 899 & 911 & 1031 \\
\hline Pressure average (bar) & 431 & 644 & 921 & 443 & 656 & 943 \\
\hline Pressure diff. particulate filter (mbar) & 0 & 1 & 8 & 3 & 4 & 13 \\
\hline Exhaust soot (\%) & 72.42 & 71.6 & 72.5 & 65.86 & 68.54 & 68.96 \\
\hline EGR position (mm) & 0 & 0 & 0 & 1 & 1 & 2 \\
\hline Lambda sensor (V) & 3 & 3.2 & 3.6 & 2.45 & 2.33 & 2.32 \\
\hline Water temperature $\left({ }^{\circ} \mathrm{C}\right)$ & 92 & 89 & 93 & 90 & 90 & 94 \\
\hline Horizontal vibration speed (mm/s) & 3.75 & 4.71 & 8.67 & 3.36 & 3.24 & 5.68 \\
\hline IEV $(W)$ & 0.56 & 3.15 & 13.72 & 0.53 & 2.42 & 9.43 \\
\hline
\end{tabular}

Looking at Table 4, we can see that the engine had an average consumption of $16 \%$ higher when using B100 fuel compared to B8 diesel per duty cycle, in contrast to the previous observation that the amount of energy dissipated by vibration is lower when used or B100 fuel. Table 4 also shows that the exhaust system exhaust filter reading is slightly higher when using the B100, which allows for lower fuel consumption than the fuel but can observe the total amount of clearance released by the system. relatively lower, values that can be confirmed by reading the oxygen sensor present in the exhaust system at the three revs analyzed that indicate lower values, or that means a greater amount of free oxygen in the exhaust.

\section{CONCLUSIONS}

When analyzing the experiments carried out, taking as main the analysis of vibration, specific consumption and level of emission of pollutants, the latter of which were obtained through readings performed by the automotive scanner, it can be concluded that the engine had a average consumption of $16 \%$ higher using b100 biodiesel fuel compared to $\mathrm{B} 8$ diesel fuel. The particle emission level was lower for the B100 biodiesel fuel, due to its chemical characteristics, which provided different combustion rates. The level of polluting particles present in exhaust gases can be observed through data collected by the scanner, noting that with the use of biodiesel B100 we obtained a greater amount of free oxygen, resulting in an amount around 7\% higher than particles when B8 diesel fuel was used. The amount of oxygen free in the exhaust gas was higher when the B100 biodiesel fuel was used. It turns out that B8 diesel fuel has greater operational stability, which can be verified through the data collected by the automotive scanner when compared to the B100 biodiesel fuel.

\section{REFERENCES}

ARNONE, L. et al. Engine block vibration measures for time detection of diesel combustion phases. SAE Technical Paper, 35(24):1-9, 2009.

ABNT. Non-destructive testing, evaluation of vibration. NBR 10082, 2011.

ABNT. Mechanical vibration, measurement and evaluation of machine vibration. NBR ISO 20816-1, 2016.

CARLUCCI, A. P, CHIARA, F. F; LAFORGIA, D. Analysis of the relation between injection parameter variation and block vibration of an internal combustion diesel engine. Journal of Sound and Vibration, 295(1-2):141-164, 2006.

CHUN, K., KIM, K. Measurement and analysis of knock in an engine using the cylinder pressure and block vibration signals. SAE Technical Paper, 940146, doi:10.4271/940146, 1994. 
HEIDARY, B. et al. Vibration analysis of a small diesel engine using diesel-biodiesel fuel blends. Agricultural Engineering International, 15(3):117-126, 2013.

HEYWOOD, J. B. Internal combustions engine fundamentals. 1.ed. USA: Publisher McGraw-Hill, 1988. 238p.

MONYEM, A.; VAN GERPEN, J.H. The effect of biodiesel oxidation on engine performance and emissions. Biomass and Bioenergy, 20(4):317-325, 2001.

ANP. Regras para a mistura de biodiesel. Available in: (http:/ / www.anp.gov.br/noticias/anp-e-p/4871mistura-biodiesel-regras-29out2018). Access in June, 2019.

PERIN, G. F. et al. Performance of an agricultural diesel engine using different fuels. Engenharia Agricola, 37(1):91-97, 2017.

RAO, S. Vibrações mecânicas. 4.ed. São Paulo: Editora Pearson, 2009. 06p.

COP 21. The Paris Agreement. Available in: (https:/ / unfccc.int/resource/docs/2015/cop21/eng/109r01. pdf). Access in June, 2019.

ULUDAMAR, E. et al. Vibration Analysis of a Diesel Engine Fuelled with Sunflower and Canola Biodiesels. Advances in Automobile Engineering, 5(1):1-5, 2016.

VOLPATO, C.E.S. et al. Performance of four stroke diesel cycle engine supplied with soybean oil biodiesel (B 100). Ciência e Agrotecnologia, 33(4): 1125-1130, 2009.

WEI, L.; CHEUNG, C.S.; NING, Z. Effects of biodiesel-ethanol and biodiesel-butanol blends on the combustion, performance and emissions of a diesel. Energy, 155(3): 957-970, 2018.

WU, J., \& CHUANG, C. Fault diagnosis of internal combustion engine using visual dot patterns of acoustic and vibration signals. NDT\&E International, 38(8): 605-614, 2005.

YANG T. et al. Vibration Characteristics of Compression Ignition Engines Fueled with Blended Petro-Diesel and Fischer-Tropsch Diesel Fuel from Coal Fuels. Energies, 11(8): 2043, 2018.
YUSOP, A. F. et al. Analysis of Particulate Matter (PM) Emissions in Diesel Engines Using Palm Oil Biodiesel Blended with Diesel Fuel. Energies. 11(5): 1039, 2018. 